\title{
An Analysis of Intermediary Metabolism and its Control in a Fat- synthesizing Yeast (Candida 107) Growing on Glucose or Alkanes
}

\author{
By D. A. WHITWORTH AND C. RATLEDGE \\ Department of Biochemistry, The University of Hull, Hull HU6 ${ }_{7} R X$
}

(Received 21 October I974; revised Iо January 1975)

\begin{abstract}
SUMMARY
Erizymes of glycolysis, pentose phosphate pathway, gluconeogenesis, tricarboxylate acid cycle, glyoxylate by-pass and fatty-acid biosynthesis were assayed in extracts from Candida 107 grown continuously on glucose under carbon limitation, nitrogen limitation and on $n$-alkanes. The yeast was therefore either in a lipogenic or lipolytic state. Phosphofructokinase was absent under all conditions whereas enzymes of gluconeogenesis, including fructose 1,6-bisphosphatase and the pentose phosphate cycle, were all present. Glucose 6-phosphate dehydrogenase and 6-phosphogluconate dehydrogenase were specific for $\mathrm{NADP}^{+}$and were inhibited in a non-competitive manner by NADPH and NADH. Phosphoenolpyruvate, citrate, ATP and acetyl CoA had no inhibitory effects. Thus glucose metabolism appears to be by the pentose phosphate pathway which will rapidly produce NADPH. This can readily be consumed during fatty-acid biosynthesis and, as there appears to be no inhibition of the flow of carbon from glucose to acetyl CoA, fatty-acid synthesis can continue for as long as there is a supply of glucose. These results help to explain the probable causes of fat build-up to high concentrations (about $40 \%$ of the cell dry weight) in this and other organisms. In alkane-grown cells, lipogenesis is repressed and carbon is able to flow from the alkanes via acetyl CoA, oxaloacetate and pyruvate into pentoses and hexoses in a unidirectional manner, because of the strong repression of pyruvate kinase and the increased activities of phosphoenolpyruvate kinase and fructose $\mathbf{I}, 6$-bisphosphatase under these conditions. Although there was little change in the total activity of the TCA cycle enzymes under the various growth conditions, isocitrate lyase was induced under lipolytic conditions.
\end{abstract}

\section{INTRODUCTION}

The ability of yeasts to grow on carbohydrates and to accumulate a large proportion of their dry weight as lipid (mainly triglyceride) has been well established (Woodbine, I959; Whitworth \& Ratledge, 1974). Under appropriate conditions, Candida I07 can produce up to $40 \%$ of its weight as lipid when grown with either carbohydrates, such as glucose or sucrose, or with $n$-alkanes as source of carbon (Ratledge, I968, I970; Thorpe \& Ratledge, 1972). The oxidation of $n$-alkanes is constitutive in this organism and, furthermore, when $n$-alkanes are added to the yeast actively growing on glucose, immediate in hibition of glucose transport and metabolism occurs (Gill \& Ratledge, 1973a). Fatty-acid biosynthesis is also inhibited, apparently by feedback inhibition of long-chain acyl CoA esters upon acetyl CoA carboxylase and the fatty-acid synthetase multienzyme complex (Gill \& Ratledge, 1973b). Exposure of Candida 107 to alkanes for up to $24 \mathrm{~h}$ eventually leads to an almost total repression of acetyl CoA carboxylase activity, and simultaneously to a partial repression of the fatty-acid synthetase (Gill \& Ratledge, 1973b). Kamiryo \& Numa (1973) noted only a partial repres- 
sion of acetyl CoA carboxylase in Saccharomyces cerevisiae after exposure to exogenous fatty acids; however, since this yeast is unable to utilize $n$-alkanes or fatty acids as sole sources of carbon, fatty acids had to be added to conventional growth medium at about I $\mathrm{g} / \mathrm{l}$.

In mammalian systems, procedures for inducing lipolysis or lipogenesis usually involve examining specific tissues under different nutritional states, e.g. starvation or feeding high fat or high carbohydrate diets. Thus effects are not specific and it is often difficult to establish which are the control enzymes. With a micro-organism, changes in the environment are not so limited. With Candida 107, for example, lipolysis or lipogenesis can be greatly stimulated by using either alkanes or carbohydrates as carbon source. Furthermore, high and low levels of lipogenic activity can be generated by growing cells at a steady state (i.e. in a chemostat) with either excess or limiting levels of carbohydrate in the medium. The lipid concentration within the cell can then be varied from about $40 \%(w / w)$ to under I0 \% (Gill, I973). The yeast serves as an adequate model for a mammalian system in that it possesses mitochondria. Problems of transport across the mitochondrial membrane are therefore similar to those encountered in mammalian cells. We investigated whether growth of the yeast under different conditions and with different substrates results in significant changes in the activity of the enzymes associated with glycolysis, gluconeogenesis, fatty-acid biosynthesis, and the tricarboxylic acid, glyoxylate and pentose phosphate cycles; we also compared enzyme levels with those found in Saccharomyces cerevisiae, a yeast which has been more extensively studied than Candida 107 but which does not have as great a range of metabolic activities.

\section{METHODS}

Growth of the organisms. Candida 107 was grown on glucose or $n$-alkanes $\left(\mathrm{C}_{13}\right.$ to $\mathrm{C}_{16}$ fraction) in continuous culture with working volumes of $\mathrm{I} \cdot 6$ to $5 \mathrm{l}$. The temperature was maintained at $30{ }^{\circ} \mathrm{C}$ and the $\mathrm{pH}$ maintained at 5.5 by adding $\mathrm{NaOH}$. Glucose medium contained $(\mathrm{g} / \mathrm{l}): \mathrm{KH}_{2} \mathrm{PO}_{4}, 7 ; \mathrm{Na}_{2} \mathrm{HPO}_{4}, 2 ; \mathrm{NH}_{4} \mathrm{Cl}, \mathrm{I} \cdot 7 ; \mathrm{MgSO}_{4} \cdot 7 \mathrm{H}_{2} \mathrm{O}, \mathrm{I} \cdot 5 ;$ yeast extract, 0.05 ; $\mathrm{CaCl}_{2} .6 \mathrm{H}_{2} \mathrm{O}, 0 . \mathrm{I} ; \mathrm{FeCl}_{3}, 0.05$; biotin, $0.005 ; \mathrm{ZnSO}_{4} .7 \mathrm{H}_{2} \mathrm{O}$, 0.000I. Glucose was added at either $12 \mathrm{~g} / 1$ (carbon-limited medium) or $45 \mathrm{~g} / \mathrm{l}$ (nitrogen-limited medium). Growth on alkanes was on the medium of Ratledge (I 968$) ; n$-alkanes containing $0.5 \%$ Span 85 were pumped separately into the fermenter to give $40 \mathrm{~g} / \mathrm{l}$.

Residual nitrogen was determined by the method of Chaney \& Marbach (1962) and glucose was measured using glucose oxidase (Boehringer Corporation Ltd, London). The total lipid content was determined by the method of Folch, Lees \& Sloane-Stanley (I 957) using packed wet cells disrupted through a French press.

Candida 107 growing in continuous culture, with glucose as the limiting nutrient, contained $9.3 \%(\mathrm{w} / \mathrm{w})$ lipid at a dilution rate of $0.15 \mathrm{~h}^{-\mathbf{1}}$. When nitrogen was the limiting nutrient and with glucose as carbon source, the lipid content was $32 \%(w / w)$ at a dilution rate of $0.08 \mathrm{~h}^{-1}$. With $n$-alkanes as carbon source, the lipid content of Candida 107 was $20 \%(\mathrm{w} / \mathrm{w})$ at a dilution rate of $0 \cdot 10 \mathrm{~h}^{-1}$. These were the steady-state conditions, i.e. weakly lipogenic, strongly lipogenic and lipolytic coupled with gluconeogenesis, which pertained at the times of taking samples for the determination of the various enzyme activities.

Saccharomyces cerevisiae (baker's yeast from Distillers Co. Ltd, Dovercourt, Essex) was grown in shake-culture on medium containing yeast extract $(0.3 \%)$, malt extract $(0.3 \%)$, peptone $(0.5 \%)$ and glucose $(\mathrm{I} \%)$, and harvested after $20 \mathrm{~h}$ growth at $30{ }^{\circ} \mathrm{C}$.

Preparation of extracts. Yeasts were harvested by centrifuging at $3000 \mathrm{~g}$ for $5 \mathrm{~min}$ (Ioooo $g$ for Io min for alkane-grown yeast) and washed twice with $50 \mathrm{~mm}$-phosphate 
buffer $\mathrm{pH} 7 \cdot 5$, containing $\mathrm{I} \mathrm{mm}-\mathrm{MgCl}_{2}$ and $0.5 \mathrm{~mm}$-dithiothreitol. The cells were then resuspended in the same buffer at a concentration of $0.3 \mathrm{~g} / \mathrm{ml}$ and disrupted within $\mathrm{I} h$ of harvesting by a single passage through a French press at $35 \mathrm{mPa}$. The material was centrifuged at $5000 \mathrm{~g}$ for $10 \mathrm{~min}$ to remove unbroken cells and debris, which were discarded; then the supernatant was centrifuged at $14000 \mathrm{~g}$ for $20 \mathrm{~min}$ to sediment any unbroken mitochondria, and at $45000 \mathrm{~g}$ for $30 \mathrm{~min}$ to sediment other particulate matter. The final supernatant, stored in an ice bath, was filtered by suction through a Whatman fibre-glass paper (grade A) to remove any solidified fat. The two precipitates were resuspended in a minimal volume of buffer and recombined. The protein concentration, established by the biuret method of Gornall, Bardawill \& David (1949), was adjusted to Io $\mathrm{mg} / \mathrm{ml}$ with the buffer.

The concentrations of protein recovered in the final supernatant fractions, after disintegration of the yeasts in the French press on two separate occasions for duplicate experiments, were (mg protein/g packed yeast): S. cerevisiae, 92 and 130; Candida 107, carbon-limited, 53 and $6 \mathrm{I}$; nitrogen-limited, 44 and 73 ; alkane grown, 35 and 53. The soluble protein which could be recovered from Candida 107 was about half that obtainable from an equivalent weight of $S$. cerevisiae.

Enzyme assays of the pentose phosphate cycle enzymes and inhibition studies with glucose 6-phosphate dehydrogenase and 6-phosphogluconate dehydrogenase were completed with carbon-limited cells with a recoverable protein content of 40 to $50 \mathrm{mg} / \mathrm{g}$ packed yeast.

The various enzyme activities were assayed by using the $45000 \mathrm{~g}$ supernatant fractions from Candida 107 and S. cerevisiae. Initial experiments used the supernatant fractions dialysed for $3 \mathrm{~h}$ against a 100 -fold excess of $50 \mathrm{mM}$-phosphate buffer $\mathrm{pH} 7.5$ containing I $\mathrm{mM}_{-} \mathrm{Mg}^{2+}$ and $\mathrm{I} \mathrm{mm}$-dithiothreitol, with a change of solution after $\mathrm{I} \cdot 5 \mathrm{~h}$. There were, however, no marked differences in any enzyme activity after dialysis and all subsequent work was carried out with undialysed material.

Chemicals. Coenzyme A was supplied by P. L. Biochemicals, Inc., Milwaukee, Wisconsin, U.S.A. Acetyl-CoA was prepared from acetic anhydride according to Simon \& Shemin (I953). Enzymes, coenzymes and enzyme substrates were from Sigma and Boehringer. The $n$-alkanes fraction used for the cultivation of the yeast contained: $2 \cdot 3 \%(\mathrm{w} / \mathrm{w}) \mathrm{C}_{13}, 55 \cdot 7 \% \mathrm{C}_{14}$, $35.3 \% \mathrm{C}_{15}$ and $6.6 \% \mathrm{C}_{16}$ and was a gift from Texaco Ltd, London. The glucose was technical grade from Fisons, Loughborough, Leicestershire. All other reagents were analytical grade. Span 85 (sorbitan-trioleate) was from Atlas Chemical Industries, Wilmington, Delaware, U.S.A.

\section{Enzyme assays}

Each enzyme activity was determined, in duplicate, upon samples prepared under identical conditions and withdrawn from the chemostats running under steady state conditions within 2 to 5 days of each other.

All continuous assays using a spectrophotometer (Unicam SP I 800) were performed with I ml cuvettes at $30{ }^{\circ} \mathrm{C}$, normally using an air reference. Reactions were initiated by the addition of substrates. The activity of each enzyme was measured over a range of protein concentrations. Endogenous activity was always subtracted from the observed rates. The maximum amount of protein used in any assay did not exceed $3 \mathrm{mg}$ and in the case of malate dehydrogenase was as low as $2 \mu \mathrm{g}$.

Assays for the following enzymes were completed within 4 to $8 \mathrm{~h}$ of harvesting: pyruvate carboxylase, phosphoenolpyruvate kinase, pyruvate and 2-oxoglutarate dehydrogenase complexes, pyruvate and 2-oxoglutarate decarboxylases, succinate thiokinase, succinate 
dehydrogenase, isocitrate lyase and ATP: citrate lyase, transketolase, ribulose phosphate 3-epimerase, ribose phosphate isomerase, transaldolase, and glucose phosphate isomerase. Other assays were completed within 24 to $28 \mathrm{~h}$. Inhibition studies with glucose 6-phosphate dehydrogenase and 6-phosphogluconate dehydrogenase were completed in 4 to $8 \mathrm{~h}$ and 24 to $28 \mathrm{~h}$, respectively.

Enzymes of glycolysis. Hexokinase (EC. 2.7.I.I; ATP:D-hexose 6-phosphotransferase) was assayed by the method of Slein, Cori \& Cori (I950), by coupling with glucose 6phosphate dehydrogenase and following the reduction of NADP+ at $340 \mathrm{~nm}$.

Glucosephosphate isomerase (EC. 5.3.I.9; D-glucose 6-phosphate ketol isomerase) was assayed by the method of Noltmann (I966), by coupling with glucose 6-phosphate dehydrogenase and following the reduction of $\mathrm{NADP}^{+}$at $340 \mathrm{~nm}$.

Phosphofructokinase (EC. 2 .7 I I I ; ATP:D-fructose 6-phosphate I-phosphotransferase) was assayed by the method of Sols \& Salas (I966), by coupling with aldolase, triose phosphate isomerase and glycerophosphate dehydrogenase and measuring the oxidation of NADH at $340 \mathrm{~nm}$.

Fructose bisphosphate aldolase (EC. 4.I.2.13; fructose I,6-bisphosphate D-glyceraldehyde 3-phosphate lyase) was assayed by the procedure of Rutter \& Hunsley (I966), by coupling with $\alpha$-glycerophosphate dehydrogenase-triose phosphate isomerase mixture and following the oxidation of NADH at $340 \mathrm{~nm}$.

Alcohol dehydrogenase (EC. I.I.I.I; alcohol: NAD ${ }^{+}$oxidoreductase) was assayed by the method of Kersters \& De Ley (I 966), following the reduction of $\mathrm{NAD}^{+}$at $340 \mathrm{~nm}$.

Pyruvate kinase (EC.2.7.I.40; ATP:pyruvate 2-O-phosphotransferase) was assayed by the method of Bücher \& Pfleiderer (1955), by coupling with lactate dehydrogenase and following the oxidation of NADH at $340 \mathrm{~nm}$.

Enzymes of pentose phosphate cycle. Glucose 6-phosphate dehydrogenase (EC. I . I I . 49; D-glucose 6-phosphate:NADP+oxidoreductase) was assayed by the method of Noltmann, Gubler \& Kuby (I96I) by measuring the initial rate of reduction of NADP $^{+}$at $340 \mathrm{~nm}$.

6-Phosphogluconate dehydrogenase(EC. 3-3 I I I I ; D-fructose I, 6-diphosphate I-phosphohydrolase) was assayed by the method of Pontremoli \& Grazi (I966), by coupling the reaction with phosphoglucoisomerase and glucose 6-phosphate dehydrogenase and following the reduction of NADP ${ }^{+}$at $340 \mathrm{~nm}$.

Transketolase (EC. 2.2.I I ; sedoheptulose 7-phosphate:D-glyceraldehyde 3-phosphate glycolaldehyde transferase) was assayed by the method of Kiely, Tan \& Wood (1969), by coupling with triose phosphate isomerase and glycerol phosphate dehydrogenase and following the oxidation of $\mathrm{NADH}$ at $340 \mathrm{~nm}$.

Ribulose phosphate 3-epimerase (EC. 5.I.3.I; D-ribulose 5-phosphate 3-epimerase) was assayed by the method of Kiely et al. (1969) based on the transketolase assay.

D-Ribose 5-phosphate ketol isomerase (EC. 5.3.I.6; D-ribose 5-phosphate ketol isomerase) was assayed by the method of Kiely et al. (I969) based on the transketolase assay.

Transaldolase (EC. 2.2.1.2; sedoheptulose 7-phosphate:D-glyceraldehyde 3-phosphate dihydroxy acetone transferase) was assayed by the method of Tchola \& Horecker ( 1966 ), by coupling with triose phosphate isomerase and glycerol phosphate dehydrogenase and following the oxidation of NADH at $340 \mathrm{~nm}$.

Enzymes of gluconeogenesis. Hexose diphosphatase (EC. 3.I.3.II; D-fructose I,6bisphosphate I-phosphohydrolase) was assayed by the method of Rosen, Rosen \& Horecker (I966), by coupling with glucose 6-phosphate dehydrogenase and phosphoglucose isomerase and following the reduction of $\mathrm{NADP}^{+}$at $340 \mathrm{~nm}$.

Phosphoenolpyruvate carboxykinase [EC. 4.I.I.49; ATP:oxaloacetate carboxy-lyase 
(transphosphorylating)] was assayed by the method of Chang \& Lane (1966) with I mMADP, by coupling with malate dehydrogenase and following the oxidation of NADH at $340 \mathrm{~nm}$.

Pyruvate carboxylase [EC. 6.4.I.I; pyruvate-carbon dioxide ligase (ADP)] was assayed by the method of Young, Tolbert \& Utter (1969), by coupling with malate dehydrogenase and following the oxidation of NADH at $340 \mathrm{~nm}$.

Enzymes of the citric acid cycle. Pyruvate and oxoglutarate dehydrogenase complexes [EC. I.2.4. I, pyruvate:lipoate oxidoreductase (decarboxylating and acceptor-acetylating); and EC. I.2.4.2, 2-oxoglutarate, lipoate oxidoreductase (decarboxylating and acceptorsuccinylating)] were assayed by the method of Reed \& Mukherjee (I969), by following the reduction of $\mathrm{NAD}^{+}$at $340 \mathrm{~nm}$.

Pyruvate and $\alpha$-ketoglutarate decarboxylases were assayed by colorimetric determination at $E_{540}$ of ferrocyanide (as Prussian blue) formed by oxidative decarboxylation of the substrates with ferricyanide as electron acceptor. The procedure described by Reed \& Williams (I966) was modified, the ferric ammonium sulphate reagent being added directly to $2 \mathrm{ml}$ of the trichloracetic-acid-terminated incubation mixture.

Citrate synthase [EC. 4.I .3.7; citrate oxaloacetate-lyase (CoA-acetylating)] was assayed by following the formation of $\mathrm{CoA}$ by coupling with 5,5'-dithiobis-(2-nitrobenzoate) (DTNB) and measuring $\Delta E_{412}$ according to the method of Srere (I 969).

Isocitrate dehydrogenases $\left(\mathrm{NAD}^{+}\right.$and NADP ${ }^{+}$linked) [EC. I.I.I.4I (42) threo-D isocitrate: $\mathrm{NAD}(\mathrm{P})^{+}$oxidoreductases (decarboxylating)] were assayed according to the method of Kornberg (1955) by following the reduction of $\mathrm{NAD}^{+}$and $\mathrm{NADP}^{+}$both at $340 \mathrm{~nm}$.

Succinate thiokinase [EC.6.2.I.5; succinate:CoA ligase (ADP)] was assayed by measuring the increase of thioester bond formation at $230 \mathrm{~nm}$ according to the method of Bridger, Ramaley \& Boyer (1969).

Succinate dehydrogenase [EC. I.3.99.I; succinate-(acceptor) oxidoreductase] was assayed by following the continuous reduction of ferricyanide at $455 \mathrm{~nm}$ according to the method of Veeger, Dervartanian \& Zeylemaker (I969).

Fumarase (EC. 4.2.I.2; L-malate hydro-lyase) was assayed by following the increase at $250 \mathrm{~nm}$ on addition of enzyme solution according to the method of Kanarek \& Hill (1964).

Malate dehydrogenase (EC.I.I.I.37; L-malate:NAD ${ }^{+}$oxidoreductase) was assayed by following the reduction of $\mathrm{NAD}^{+}$at $340 \mathrm{~nm}$ according to the method of Englard \& Siegel (1969).

Enzymes of the glyoxylate by-pass. Isocitrate lyase (EC. $4 . \mathrm{I} \cdot 3 . \mathrm{I}$; threo- $\mathrm{D}_{\mathrm{8}}$-isocitrate glyoxylate-lyase) was assayed by measuring the amount of glyoxylate formed from isocitrate in 10 min, using a specific colorimetric procedure described by McFadden (I969).

Malate synthase [EC. 4.I.3.2; L-malate glyoxylate-lyase (CoA-acetylating)] was assayed either by following the formation of $\mathrm{CoA}$ by coupling with $5,5^{\prime}$-dithiobis-(2-nitrobenzoate) and measuring the change in absorption at $4 \mathrm{I} 2 \mathrm{~nm}$ according to the method of Griffiths \& Sundaram (I973), or by the method of Dixon \& Kornberg (I962) following the decrease in extinction at $232 \mathrm{~nm}$ following breakage of the thioester bond.

Enzymes of fatty-acid biosynthesis. ATP citrate lyase [EC. 4.I.3.8; ATP: citrate oxaloacetate lyase (CoA-acetylating and ATP-dephosphorylating)] was assayed by trapping the acetyl $\mathrm{CoA}$ formed as acetyl hydroxamate over $30 \mathrm{~min}$ and measuring the colour formed with $\mathrm{FeCl}_{3}$ at $520 \mathrm{~nm}$, following the procedure described by Takeda, Suzuki \& Inoue (1969) using $2 \mu \mathrm{mol}$ coenzyme A.

Malate enzyme [EC. I.I.I.40; L-malate:NADP ${ }^{+}$oxidoreductase (decarboxylating)] 


\section{Table I. Enzyme activities of the yeast extracts}

With alkane-grown yeast, the first sample (Expt I) was removed 3 days after inoculation with a glucose grown culture and the second sample (Expt 2) was removed 8 days after inoculation.

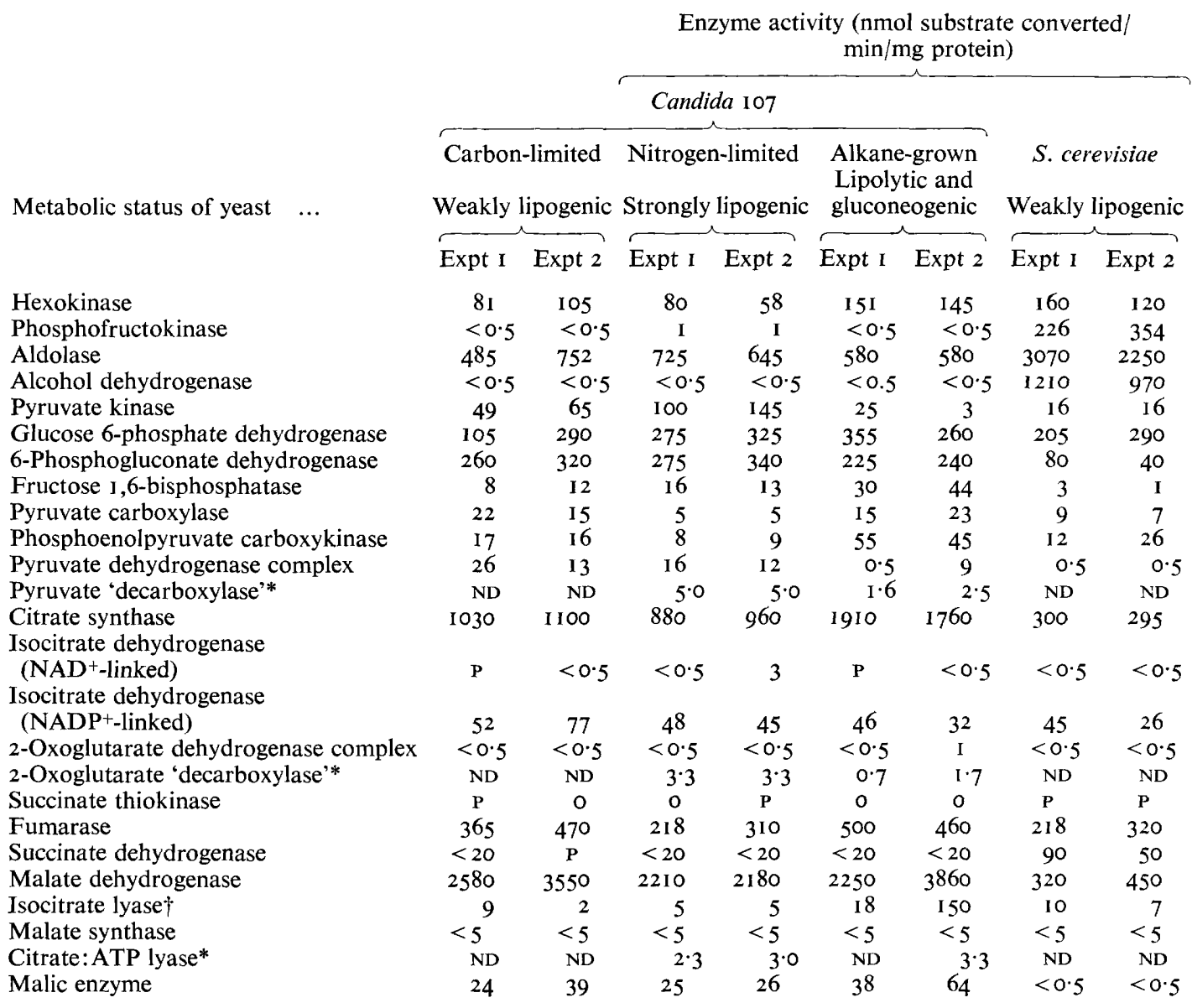

ND, Not determined; $P$, slight trace of activity in the precipitate fraction. * Average measured over first 30 min of reaction. $\dagger$ Average measured over first 10 min of reaction.

was assayed by following the reduction of $\mathrm{NADP}^{+}$at $340 \mathrm{~nm}$ according to the method of Hsu \& Lardy (I969), except that I mM- $\mathrm{MnCl}_{2}$ was used.

\section{RESULTS}

Activities of most enzymes in Candida 107 grown under different conditions (Table I) were located predominantly in the soluble fraction after disruption of the yeast, the exceptions being succinate thiokinase and succinate dehydrogenase. The two citric acid cycle enzymes, 2-oxyglutarate dehydrogenase complex and $\mathrm{NAD}^{+}$-linked isocitrate dehydrogenase, were barely detectable in either the soluble or precipitate fractions, suggesting the 
Table 2. Activities of enzymes of the pentose phosphate pathway in Candida 107

Activity

(nmol substrate converted/min/mg

protein)

Enzyme*

Glucosephosphate isomerase

Ribosephosphate isomerase

Ribulose phosphate 3-epimerase

Transketolase

Transaldolase

$\begin{array}{rr}\text { Expt I } & \text { Expt } 2 \\ 830 & 1610 \\ 185 & 105 \\ 37 & 80 \\ 28 & 215 \\ 19 & 215\end{array}$

* Extracts of glucose-grown (carbon limited) yeast, i.e. weakly lipogenic, were used.

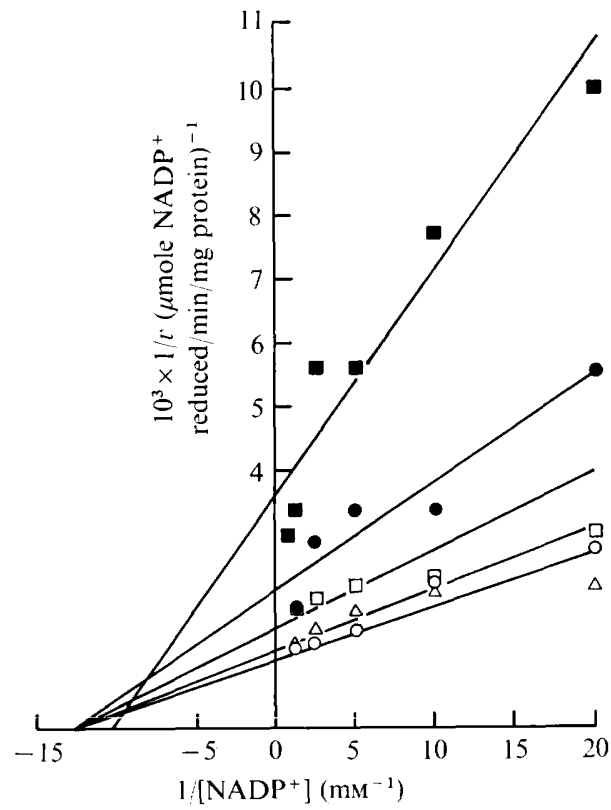

Fig. I. Double reciprocal plot of the effect of NADP $^{+}$concentration on glucose 6-phosphate dehydrogenase activity and inhibitory effect of different levels of NADH and NADPH. The cuvettes at $30{ }^{\circ} \mathrm{C}$ contained $50 \mu \mathrm{g}$ enzyme protein and I $\mu \mathrm{mol}$ glucose 6 -phosphate in a total volume of I ml. O, NADP + alone; $\square$, +o.I mM-NADPH; O, +0.3 mM-NADPH; $\square,+0.5$ mM$\mathrm{NADPH} ; \triangle,+0.2 \mathrm{~mm}-\mathrm{NADH}$.

disruption of the complex in the former case since the decarboxylase activity of this enzyme could be measured.

Malate synthase was not measurable by the two assay procedures employed, presumably because of either a low activity or, more likely, competing levels of acetyl CoA deacylase present in the crude extract.

When malate enzyme was assayed while using the recommended concentration of $\mathrm{MnCl}_{2}$, i.e. $5 \mathrm{mM}$, turbidity resulted. However, with $\mathrm{I} \mathrm{mM}^{-} \mathrm{MnCl}_{2}$, optimum activity was present without the occurrence of turbidity. The enzyme showed a specific requirement for $\mathrm{Mn}^{2+}$; $\mathrm{Mg}^{2+}$ would not substitute.

Phosphofructokinase activity was assayed using I mM-GTP as the phosphorylating 


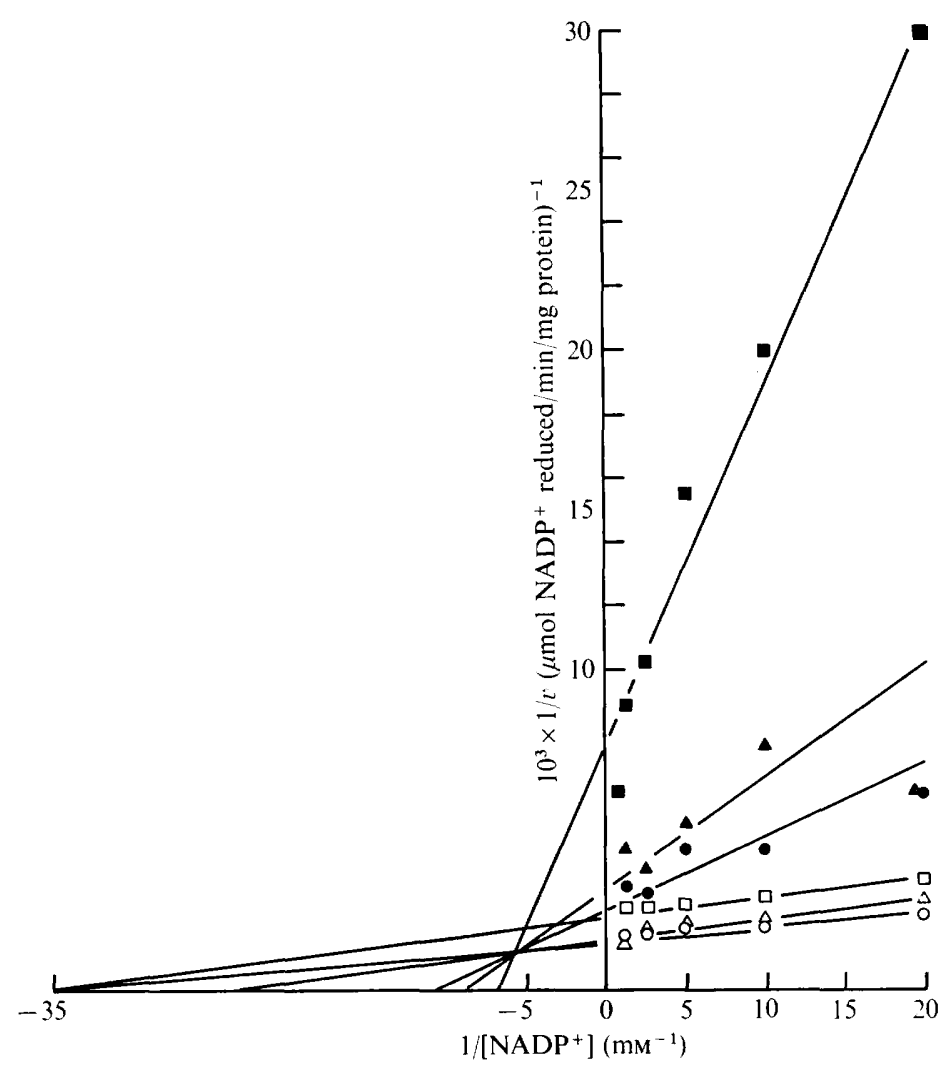

Fig. 2. Double reciprocal plot of the effect of NADP+ concentration on 6-phosphogluconate dehydrogenase activity and inhibitory effect of different levels of NADH and NADPH. The cuvettes at $30{ }^{\circ} \mathrm{C}$ contained $50 \mu \mathrm{g}$ enzyme protein extract and $2 \mu \mathrm{mol} 6$-phosphogluconate in a total volume of $\mathrm{I}$ ml. $\bigcirc$, NADP ${ }^{+}$alone; $\square,+0.1$ mM-NADPH;,+0.3 mM-NADPH; $\mathbf{0},+0.5$ mM-NADPH; $\triangle,+0.2$ mM-NADH; $\Delta,+0.4$ mm-NADH.

nucleotide, since ATP specifically inhibits at higher concentrations $\left(K_{i}=0.1 \mathrm{~mm}\right)$ (Sols, 1967; Mansour, 1972). As no activity was shown with extracts from Candida 107, other nucleotides were substituted: ITP, UTP and CTP at I mM, and ATP at I, 0.I, 0.5 and O.OI $\mathrm{mM}$; there was still no significant activity, however. Since the assay system successfully and repeatedly found this enzyme in high activity in extracts of $S$. cerevisiae, phosphofructokinase appears to be almost completely absent in Candida I07 regardless of growth conditions.

Pyruvate kinase displayed a marked difference in activity according to the growth conditions (Table I). With alkane-grown yeast, the activity, particularly in Expt 2, was strongly repressed. This result was confirmed when a sample taken from the fermenter, after 7 days cultivation on $n$-alkanes following inoculation from a glucose-grown culture, gave an activity of $4.5 \mathrm{nmol}$ substrate converted $/ \mathrm{min} / \mathrm{mg}$ protein.

The results from the initial series of experiments (Table I) suggested that since phosphofructokinase was absent in Candida I07, glucose catabolism would probably proceed via the pentose phosphate cycle. A further series of experiments using only extracts from glucose-grown (carbon-limited) Candida 107 was undertaken to establish the presence of 
the pentose phosphate cycle. The results (Table 2) showed that all the enzymes of the pentose phosphate cycle were present and that this pathway was most likely the principal pathway for glucose metabolism. In this work, activities of some enzymes varied between the two preparations, probably because of their lability or slight changes in the method of disrupting the yeast. No significance is attached to these changes.

In organisms having a functional glycolytic pathway, control is maintained by inhibition of phosphofructokinase by ATP and citrate. Since phosphofructokinase is absent in Candida 107, experiments were undertaken to establish whether the enzymes for the first steps of glucose oxidation, namely glucose 6-phosphate dehydrogenase and 6-phosphogluconate dehydrogenase, were subject to similar control mechanisms by products of metabolism. Neither citrate, phosphoenolpyruvate or ATP at $25 \mathrm{~mm}$, nor acetyl-CoA at I $\mathrm{mm}$ inhibited glucose 6-phosphate or 6-phosphogluconate dehydrogenase. However, NADPH and NADH at over O.I mM were inhibitory to both enzymes, which were found to have a specific requirement for $\mathrm{NADP}^{+}$. Although only crude extracts were used in an examination of this inhibition, results showed that for both enzymes the inhibition was non-competitive in nature and a reduction in $K_{m}$ occurred only at higher concentrations $(>0.3 \mathrm{~mm}$ ) of the inhibitor (Figs. I, 2). NADPH was a more effective inhibitor than NADH. At low concentrations of $\mathrm{NAD}(\mathrm{P}) \mathrm{H}$ (about $\mathrm{O} \cdot \mathrm{I} \mathrm{mM}$ ), inhibition was very slight and each reaction could proceed at a near optimal rate.

\section{DISCUSSION}

Although we have measured the activities of many of the enzymes involved in the central pathways of metabolism, we cannot yet judge whether these enzymes are operating at or near to their maximum activities. However, highly active enzymes would indicate an enhanced potential for activity, whilst a completely, or partially, repressed activity would imply a total inability or restricted ability for metabolism to proceed via a given pathway. The interrelationships of the enzymes we have examined, with the metabolic pathways considered to be present in the yeast, are shown in Fig. 3.

An observed lack of phosphofructokinase in this yeast parallels observations by Brady \& Chambliss (1967), who reported an absence of phosphofructokinase in several species of Rhodotorula including those which are able to produce a high intracellular concentration of lipid. Höfer (1968) (see also Kleinzeller \& Kotyk, I968; Janda \& Kotyk, 1972) also reported the same result and, in later studies (Höfer et al. I97I) provided confirmation that the pentose phosphate pathway is the predominant mechanism for carbohydrate metabolism in Rhodotorula gracilis.

Evidently in Candida 107 also, the pentose phosphate pathway is the main one for carbohydrate degradation. This leads to a rapid production of NADPH. If the concentration of this is not allowed to build up, i.e. if it is equally rapidly removed, then glucose degradation will proceed unchecked since the enzymes for hexose phosphate oxidation are not inhibited by products which in other organisms would have caused an inhibition of phosphofructokinase. The fatty-acid synthetase system, which is also located in the cytoplasm, is the probable major utilizer of NADPH (see Kather, Rivera \& Brand, I972 $a, b$ ), so that in Candida 107 the rate of glucose utilization is correlated directly with lipogenesis.

Although the control experiments with glucose 6-phosphate dehydrogenase and 6phosphogluconate dehydrogenase used only crude enzyme extracts, the patterns of inhibition were unlike the typical glucose 6-phosphate dehydrogenase from rat liver described by Eggleston \& Krebs (1974), which is subject to competitive inhibition above a ratio of 


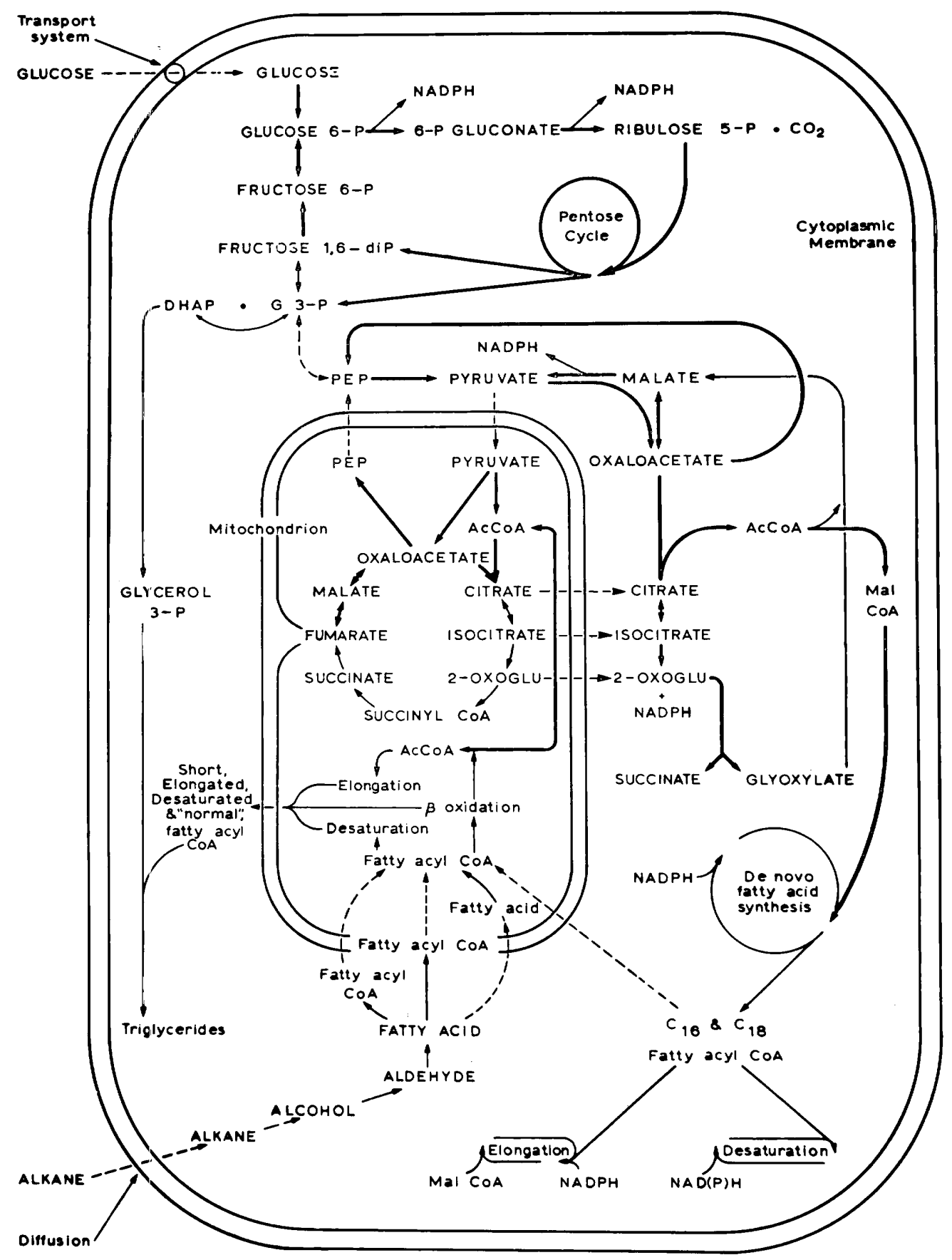

Fig. 3. Metabolism of glucose and alkanes and fatty-acid biosynthesis in Candida I07. Thick lines represent enzymes shown to be present in this paper or previous publications; thin lines represent enzymes usually present in microbial material. AcCoA, acetyl CoA; DHAP, dihydroxyacetone phosphate; G 3-P, glyceraldehyde 3-phosphate; mal CoA, malonyl CoA. 
NADPH to NADP ${ }^{+}$of 8:I (the normal state within the liver). In Candida I07, inhibition is non-competitive and, although we do not know the NADPH/NADP ${ }^{+}$ratio in the cell or the absolute concentrations of these reactants, the system here is rather different. In this connexion Senior \& Dawes (197I), examining the metabolism of Azotobacter beijerinckii which accumulates poly- $\beta$-hydroxybutyrate as a lipid storage compound, also found the glucose 6-phosphate dehydrogenase to be non-competitively inhibited by NAD(P)H with no decrease in the $K_{m}$ value. However, in Azotobacter the enzyme was subject to allosteric inhibition by ATP. Glucose 6-phosphate dehydrogenase in Candida utilis and brewer's yeast are both strongly inhibited by ATP (Afolayan, 1972; Horne, Anderson \& Nordlie, 1970) and, although purified enzymes were used in these studies, they appear to be different from the enzyme obtained from Candida 107.

In Candida 107, citrate and ATP can apparently rise to relatively high concentrations without decreasing the rate of glucose oxidation. As citrate, in conjunction with ATP and the action of ATP: citrate lyase, is the precursor for acetyl-CoA, as well as being an activator for acetyl-CoA carboxylase (Gill \& Ratledge, I973 $b$ ), lipogenesis can therefore proceed without any restrictions in the supply of carbon or of NADPH as mentioned above.

Hexokinase was present in Candida 107 under all growth conditions at an activity not dissimilar to that found in baker's yeast. The inhibition of glucose uptake which was observed upon adding alkanes to the yeast growing on glucose or upon cultivating the yeast on alkanes (Gill \& Ratledge, 1973a) cannot therefore be explained by a repression of this enzyme. However, as fatty-acid biosynthesis was repressed under these conditions and since hexose-phosphate oxidation was still fully operational, utilization of NADPH would not be as rapid as before and thus would fail to regenerate the $\mathrm{NADP}^{+}$needed for glucose 6-phosphate dehydrogenase (see also Haut, London \& Garfinkel, 1974). High concentrations of NADPH and glucose 6-phosphate would accumulate and thus be inhibitory to glucose 6-phosphate dehydrogenase (see also Opheim \& Bernlohr, 1973) and 6-phosphogluconate dehydrogenase, and to hexokinase, respectively.

Malate enyzme, although absent in baker's yeast, was found in Candida 107 under all growth conditions. This enzyme, by oxidatively decarboxylating cytosolic malate, provides a supplementary source of NADPH for lipogenesis. Malate, as well as being a product of the glyoxylate by-pass, is produced by malate dehydrogenase from oxalacetate, which is a product of ATP: citrate lyase action. The existence of a pyruvate carboxylase also within the cytosol indicates the possible operation of the pyruvate transhydrogenation cycle for regeneration of NADPH (Greville, 1969).

Another role of malate enzyme is to ensure a supply of pyruvate for alanine production in cells where pyruvate kinase is repressed. The activity of pyruvate kinase in extracts of Candida 107 varied according to the growth conditions, being almost completely repressed in $n$-alkane-grown cells. Although the properties of pyruvate kinase can vary according to its biological source, it is an important regulatory point in glycolysis (Seubert \& Schoner, 1971). Its strong repression in alkane-grown yeast ensures a unidirectional flow of carbon from acetyl-CoA, produced by alkane oxidation, via oxaloacetate and pyruvate to the pentoses and hexoses. Pyruvate kinase is probably under the control of a different operon from other enzymes of the glycolytic pathway (Hommes, 1966). Phosphoenolpyruvate kinase and fructose I,6-bisphosphatase were notably increased in activity during lipolysis and obviously contribute to the biosynthesis of carbohydrates when $n$-alkanes are the growth substrates. This contrasts with the observations of Brady (I969) who, growing four species of Rhodotorula under gluconeogenic conditions (a defined malate medium), noted an absence of fructose I,6-bisphosphatase although aldolase was present. 
The enzymes of the citric acid cycle in Candida 107 did not change significantly in activity on changing from glucose to alkanes as a carbon source for growth. Citrate synthase, particularly in alkane-grown yeast, was present at levels significantly in excess of those found in baker's yeast. Malate dehydrogenase was also present at a very high activity, although no explanation for this is apparent. ATP: citrate lyase was present in both glucose- and alkane-grown yeast, and although it was detectable only at low levels it was still in excess of the levels of acetyl-CoA carboxylase and fatty-acid synthetase noted previously in Candida 107 (Gill \& Ratledge, 1973b) and supports the earlier conclusion that fatty acid synthesis is controlled after ATP: citrate lyase.

Although malate synthetase activity could not be detected by the assay methods used, isocitrate lyase was induced under lipolytic conditions and the complete glyoxylate by-pass was assumed to be active (see also Trust \& Millis, I970; Hildebrandt \& Weide, 1974).

D.A.W. thanks the Science Research Council for a post-doctoral fellowship under grant $\mathrm{B} / \mathrm{RG} / 539 \mathrm{I} .9$ in support of this work. We are indebted to $\mathrm{Mr} \mathrm{M}$. J. Hall for his technical assistance with the chemostat cultivation of the yeast.

\section{REFERENCES}

Afolayan, A. (1972). Regulation and kinetics of glucose 6-phosphate dehydrogenase from Candida utilis. Biochemistry II, 4172-4I78.

BRADY, R. J. (1969). Lack of fructose diphosphatase activity in Rhodotorula glutinis. Bacteriological Proceedings, I34.

Brady, R. J. \& Chambliss, G. H. (I967). The lack of phosphofructokinase activity in several species of Rhodotorula. Biochemical and Biophysical Research Communications 29, 343-348.

Bridger, W. A., Ramaley, R. F. \& Boyer, P. D. (1969). Succinyl coenzyme A synthetase from Escherichia coli. In Methods in Enzymology, vol. 13, pp. 70-75. Edited by J. M. Lowenstein. New York and London: Academic Press.

Bucher, T. \& Pfleiderer, G. (I955). Pyruvate kinase from muscle. In Methods in Enzymology, vol. I, pp. 435-440. Edited by S. P. Colowick and N. O. Kaplan. New York and London: Academic Press.

Chaney, A. L. \& Marbach, E. P. (1962). Modified reagents for determination of urea and ammonia. Clinical Chemistry 8, I30-I 32.

Chang, H. C. \& LANE, M. D. (I966). The enzymatic carboxylation of phosphoenol pyruvate. Journal of Biological Chemistry 24I, 2413-2420.

Dixon, G. H. \& KorNBerG, H. L. (I962). Malate synthetase from baker's yeast. In Methods in Enzymology, vol. 5, pp. 633-637. Edited by S. P. Colowick and N. O. Kaplan. New York and London: Academic Press.

EgGleston, L. V. \& KreBs, H. A. (1974). Regulation of the pentose phosphate cycle. Biochemical Journal I38, 425-435.

Englard, S. \& Siegel, L. (I969). Mitochondrial L-malate dehydrogenase of beef heart. In Methods in Enzymology, vol. I3, pp. 99-106. Edited by J. M. Lowenstein. New York and London: Academic Press.

Folch, J., Lees, M. \& Sloane-Stanley, G. H. (1957). A simple method for the isolation and purification of total lipids from animal tissues. Journal of Biological Chemistry 226, 497-509.

GiLL, C. O. (1973). The physiology of a yeast Candida sp. strain 107, metabolizing n-alkanes. Ph.D. thesis, University of Hull.

Gill, C. O. \& RATLEDGE, C. (I973a). Inhibition of glucose assimilation and transport by $n$-decane and other $n$-alkanes in Candida 107. Journal of General Microbiology 75, I I-22.

Gill, C. O. \& RATLEDGE, C. (1973 $b$ ). Regulation of de novo fatty acid biosynthesis in the $n$-alkane utilizing yeast, Candida 107. Journal of General Microbiology 78, 337-347.

Gornall, A. G., Bardawill, C. J. \& David, M. M. (1949). Determination of serum proteins by means of the biuret reaction. Journal of Biological Chemistry I77, 75I-766.

Greville, G. D. (1969). Intracellular compartmentation and the citric acid cycle. In Citric Acid Cycle, pp. I-I 36. Edited by J. M. Lowenstein. New York and London: Marcel Dekker. 
Griffiths, M. W. \& Sundaram, T. K. (1973). Isocitrate lyase from a thermophilic Bacillus: effect of salts on enzyme activity. Journal of Bacteriology I16, I I60-I I69.

Haut, M. J., London, J. W. \& Garfinkel, D. (I974). Simulation of the pentose cycle in lactating rat mammary gland. Biochemical Journal $\mathbf{1 3 8}, 5 \mathrm{I} \mathbf{1}-524$.

Hildebrandt, W. \& WeIde, H. ( I974). Isocitratlyase von Candida guilliermondii, Stamm Hi 7. III. Regelung durch Intermediate des Alkanabbaus und allgemeines Regulationsmodell. Zeitschrift fïr allgemeine Mikrobiologie 14, 47-52.

HöFER, M. (1968). Estimation of pathways of glucose catabolism in Rhodotorula gracilis. Folia Microbiologica (Praha) 13, 373-377.

Höfer, M., Brand, K., Deckner, K. \& Becker, J.-U. (I97I). Importance of the pentose phosphate pathway for D-glucose catabolism in the obligatory aerobic yeast Rhodotorula gracilis. Biochemical Journal I23, 855-863.

Hommes, F. A. (I966). Effect of glucose on the level of glycolytic enzymes in yeast. Archives of Biochemistry and Biophysics $\mathbf{1} \mathbf{4}, 23 \mathrm{I}-233$.

Horne, R. W., Anderson, W. B. \& Nordlie, R. C. (1970). Glucose dehydrogenase activity of yeast glucose 6-phosphate dehydrogenase. Inhibition by ATP and other nucleoside 5'triphosphates and diphosphates. Biochemistry 9, 610-616.

Hsu, R. Y. \& LARdy, H. A. (1 969). Malic enzyme. In Methods in Enzymology, vol. I3, pp. 230-235. Edited by J. M. Lowenstein. New York and London: Academic Press.

JANDA, S. \& KotYK, A. (1972). Some features of carbohydrate metabolism in Rhodotorula glutinis. Folia Microbiologica (Praha) 17, 46I-470.

Kamiryo, T. \& Numa, S. (1973). Reduction of the acetyl CoA carboxylate content of Saccharomyces cerevisiae by exogenous fatty acids. FEBS Letters 38, 29-32.

KANAREK, L. \& Hill, R. L. (1964). The preparation and characterization of fumarase from swine heart muscle. Journal of Biological Chemistry 239, 4202-4206.

KATHER, H., Rivera, M. \& BRAND, K. (1972a). Interrelationship and control of glucose metabolism and lipogenesis in isolated fat cells. Effect of the amount of glucose uptake on the rates of the pentose phosphate cycle and of fatty acid synthesis. Biochemical Journal 128, 1089-1096.

Kather, H., Rivera, M. \& Brand, K. (I972b). Interrelationship and control of glucose metabolism and lipogenesis in isolated fat cells. Control of pentose phosphate cycle activity by cellular requirement for reduced nicotinamide dinucleotide phosphate. Biochemical Journal 128, 1097-I 102.

Kersters, K. \& De Ley, J. (1966). Primary and secondary alcohol dehydrogenases from Gluconobacter. I. Soluble NAD+-linked primary and secondary alcohol dehydrogenases. In Methods in Enzymology, vol. 9, pp. 346-35o. Edited by W. A. Wood. New York and London: Academic Press.

KIEly, M. E., TAN, E. L. \& WoOd, T. (I969). The purification of transketolase from Candida utilis. Canadian Journal of Biochemistry 47, 455-460.

Kleinzeller, A. \& Kotyk A. (1968). Transport of mono-saccharides in yeast cells and its relationship to cell metabolism. In Aspects of Yeast Metabolism, pp. 33-45. Edited by A. K. Mills and H. Krebs. Oxford and Edinburgh: Blackwell Scientific Publications.

KornberG, A. (I 955). Isocitric dehydrogenase of yeast. In Methods of Enzymology, vol. I, pp. 705-709. Edited by S. P. Colowick and N. O. Kaplan. New York and London: Academic Press.

Mansour, T. E. (1972). Phosphofructokinase. In Current Topics in Cellular Regulation, vol. 5, pp. I-46. Edited by B. L. Horecker and E. R. Stadtman. New York and London: Academic Press.

McFadden, B. A. (1969). Isocitrate lyase. In Methods in Enzymology, vol. 13, pp. I63-I 70. Edited by J. M. Lowenstein. New York and London: Academic Press.

Noltmann, E. A. (1966). Phosphoglucose isomerase. In Methods in Enzymology, vol. 9, pp. 557-565. Edited by W. A. Wood. New York and London: Academic Press.

Noltmann, E. A., Gubler, C. J. \& Kuby, S. A. (I96I). Glucose 6-phosphate dehydrogenase (Zwischenferment). Journal of Biological Chemistry 236, 1225-1230.

Opheim, D. \& Bernlohr, R. W. (I973). Purification and regulation of glucose 6-phosphate dehydrogenase from Bacillus licheniformis. Journal of Bacteriology I 16, I I 50-I 159.

Pontremoli, S. \& Grazi, E. (I966). 6-Phosphogluconate dehydrogenase-crystalline. In Methods in Enzymology, vol. 9, pp. I 37-14I. Edited by W. A. Wood. New York and London: Academic Press.

RAtledge, C. (I 968). Production of fatty acids and lipid by a Candida sp. growing on a fraction of $n$-alkanes predominating in tridecane. Biotechnology and Bioengineering 1o, $5 \mathrm{I}$ I-533.

RATLEDGE, C. (1970). Microbial conversions of $n$-alkanes to fatty acids: a new attempt to obtain economical fats and fatty acids. Chemistry and Industry $843-854$. 
Reed, L. J. \& Williams, C. R. (1966). Purification and resolution of the pyruvate dehydrogenase complex [Escherichia coli]. B. Pyruvate decarboxylase. In Methods in Enzymology, vol. 9, pp. 258-26r. Edited by J. M. Lowenstein. New York and London: Academic Press.

REED, L. J. \& MUKHERJEE, B. B. (I969). $\alpha$-Ketoglutarate dehydrogenase complex from Escherichia coli. In Methods in Enzymology, vol. I3, pp. 55-61. Edited by J. M. Lowenstein. New York and London: Academic Press.

Rosen, O. M., Rosen, S. M. \& Horecker, B. L. (1966). Fructose I,6-diphosphatase, II Candida utilis. In Methods in Enzymology, vol. 9, pp. 632-636. Edited by W. A. Wood. New York and London: Academic Press.

RutTeR, W. J. \& Hunsley, J. R. (1966). Fructose diphosphate aldolase, I. Yeast. In Methods in Enzymology, vol. 9, pp. 480-486. Edited by W. A. Wood. New York and London: Academic Press.

Senior, P. J. \& Dawes, E. A. (I971). Poly- $\beta$-hydroxybutyrate biosynthesis and the regulation of glucose metabolism in Azotobacter beijerinckii. Biochemical Journal 125, 55-66.

Seubert, W. \& Schoner, W. (1971). The regulation of pyruvate kinase. In Current Topics in Cellular Regulation, vol. 3, pp. 237-267. New York and London: Academic Press.

Stein, M. W., CoRI, G. T. \& CORI, C. F. (1950). A comparative study of hexokinase from yeast and animal tissues. Journal of Biological Chemistry I86, 763-780.

Simon, E. J. \& SHEmin, D. (1953). The preparation of s-succinyl coenzyme A. Journal of the American Chemical Society 75, 2520.

Sols, A. (1967). Regulation of carbohydrate transport and metabolism in yeast. In Aspects of Yeast Metabolism, pp. 47-70. Edited by A. K. Mills and H. Krebs. Oxford and Edinburgh: Blackwell Scientific Publications.

Sols, A. \& Salas, M. L. (I966). Phosphofructokinase, III: Yeast. In Methods in Enzymology, vol. 9, pp. 436-442. Edited by W. A. Wood. New York and London: Academic Press.

Srere, P. A. (1969). Citrate synthase. In Methods in Enzymology, vol. 13, pp. 3-II. Edited by J. M. Lowenstein. New York and London: Academic Press.

TAKedA, Y., Suzuki, F. \& INOUE, H. (I969). ATP citrate lyase (citrate-cleavage enzyme). In Methods in Enzymology, vol. 13, pp. I53-I60. Edited by J. M. Lowenstein. New York and London: Academic Press.

TChOla, O. \& HoReCKer, B. L. (1966). Transaldolase. In Methods in Enzymology, vol. 9, pp. 499-505. Edited by W. A. Wood. New York and London: Academic Press.

Thorpe, R. F. \& RATLEDGE, C. (1972). Fatty acid distribution in triglycerides of yeasts grown on glucose of $n$-alkanes. Journal of General Microbiology 72, $15 \mathrm{I}-163$.

Trust, T. J. \& MiluIs, N. F. (1970). The isolation and characterization of alkane-oxidizing organisms and the effect of growth substrate on isocitrate lyase. Journal of General Microbiology 6r, 245-254.

Veeger, C., Dervartanian, D. V. \& Zeylemaker, W. P. (I969). Succinate dehydrogenase. In Methods in Enzymology, vol. 13, pp. 8I-90. Edited by J. M. Lowenstein. New York and London: Academic Press.

Whitworth, D. A. \& RATLedge, C. (1974). Micro-organisms as a potential source of oils and fats. Process Biochemistry 9 (9), pp. 14, 15, 17, 19, 21, 22.

WoodBinE, M. (1959). Microbial fat: micro-organisms as potential fat producers. In Progress in Industrial Microbiology, vol. I, pp. I8I-245. Edited by D. J. D. Hockenhull. London: Heywood.

Young, M. R., TOlbert, B. \& UtTER, M. F. (1969). Pyruvate carboxylase from Saccharomyces cerevisiae. In Methods in Enzymology, vol. I 3 pp. 250-258. Edited by J. M. Lowenstein. New York and London: Academic Press. 